
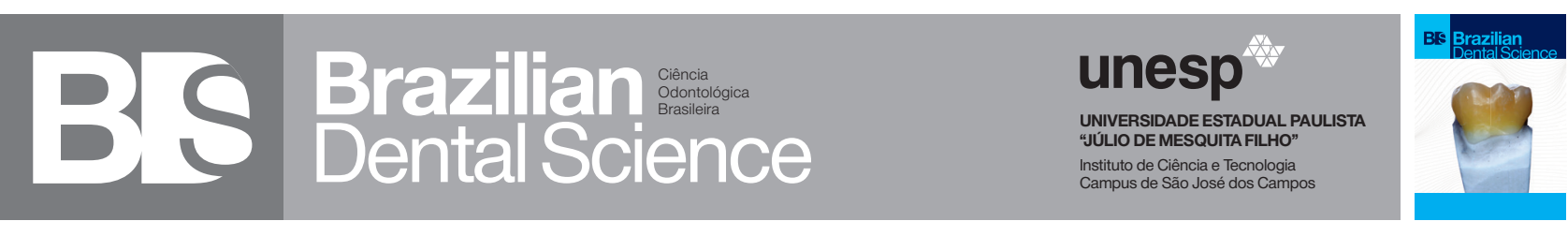

\title{
Influence of different types of light curing units and photoinitiators in microhardness and color of composite resins after immersion in wine
}

Influencia dos diferentes tipos de unidade fotoativadoras e fotoiniciadores na microdureza e cor de resinas compostas após imersão em vinho

Morganna Borges de Almeida SOUZA ${ }^{1}$, André Luiz Fraga BRISO ${ }^{1}$, Fernanda de Souza e Silva RAMOS ${ }^{1}$, Bruna de Oliveira REIS ${ }^{1}$, Paulo Henrique dos SANTOS $^{2}$, Ticiane Cestari FAGUNDES ${ }^{1}$

1 - São Paulo State University (Unesp) - Araçatuba School of Dentistry - Department of Restorative Dentistry - Araçatuba - SP - Brazil.

2 - São Paulo State University (Unesp) - Araçatuba School of Dentistry - Department of Dental Materials and Prosthodontics - Araçatuba - SP - Brazil.

\section{ABSTRACT}

Objective: the aim of this study is to evaluate the microhardness and color change $(\Delta \mathrm{E})$ of composite resins, that were light-cured with different LEDs, after being immersed in a staining drink.

Material and Methods: Two composite resins with Lucerin-TPO (Tetric N-Ceram/ Vit-l-escence) and camphorquinone (Filtek Z350) were selected. The specimens $(n=120)$ were prepared and lightcured with LED of monowave or polywave lightemitting diode (LED) devices. Microhardness and color evaluations were measured before and after immersion in staining drink. Microhardness data were evaluated by Kruskal-Wallis test, MannWhitney and Wilcoxon tests. Color changes were evaluated by two-way analysis of variance (ANOVA) and Tukey test ( $\mathrm{p} \leq$ 0.05). Results: No statistically significant difference between the two generations of LEDs was found for microhardness data. Regarding the $\Delta \mathrm{E}$, a statistical difference between the two LEDs was observed for Tetric NCeram and Filtek Z350. Conclusion: The compostion of composites appears to have more influence on analyses than the type of LEDs used. A decreased microhardness occurred to Vit-1escence for monowave and to Filtek Z350 for both LED devices. A clinically perceptible color change was observed for Tetric-N Ceram and Filtek Z350 when polywave LED were used.

\section{KEYWORDS}

Composite resins; Curing lights; Dental resin; Photoinitiators; Resin photoinitiators.

\section{RESUMO}

Objetivo: o objetivo deste estudo foi aviliar a microdureza e alteração de cor $(\Delta \mathrm{E})$ de resinas compostas, fotoativadas com diferentes LEDs, imergidas em bebidas pigmetadas. Material e métodos: Duas resinas compostas com Lucerina-TPO (Tetric N-Ceram/ VIt-l-essence) e canforoquinona (Filtek Z350) foram selecionadas. Os espécimes $(n=120)$ foram preparados. Os mesmos foram fotopolimerizados com LED monowave ou polywave. Microdureza e cor foram avaliadas antes e após a imersão em bebidas pigmentadas. Os dados de microdureza foram avaliados pelos testes de Kruskal-Wallis, Mann-Whitney e Wilcoxon. As alterações de cor foram avaliadas por análise de variância a dois critérios (ANOVA) e Tukey ( $p \leq 0,05)$. Resultados: Não foi encontrada diferença estatística entre as duas gerações de LEDs, para os dados da microdureza. Quanto ao $\Delta \mathrm{E}$, foi encontrada diferença estatisticamente significante entre os dois LEDs, sendo observadas na Tetric N-Ceram na FIltek Z350. Conclusão: A composição das resinas compostas parece ter mais influencia nas análises do que o tipo de LEDs. Uma redução na microdureza ocorreu para Vit-lescence para monowave e para Filtek Z350 para ambos os dispositivos LED. Uma mudança de cor clinicamente perceptível foi observada em Tetric-N Ceram para polywave e Filtek Z350 para ambos os dispositivos LED.

\section{PALAVRAS-CHAVE}

Fotoiniciadores; Fotoiniciadores dentários; Luzes de cura dentária; Polimerização; Resinas compostas. 


\section{INTRODUCTION}

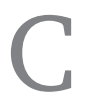
amphorquinone has traditionally used in composite resins whose activation peak occurs at a wavelength of approximately $460 \mathrm{~nm}$ [1]. However, its intense yellow color has limited its use, particularly in resin materials used for bleached teeth [2]. Thus, other photoinitiators have been used for these materials, such as phenylpropanodione and Lucerin-TPO [2]. A composite resin with deficiencies in the polymerization of the organic matrix undergoes degradation and hence changes in their mechanical properties, making them more susceptible to reduced mechanical strength and color stability [3-5].

Intrinsic and extrinsic sources can influence the color stability of composite resins. The intrinsic factors are resin matrix composition, type of photoinitiators, filler, particle size distribution and degree of conversion. The extrinsic factors are ambient, heat, water, and food stains [3]. Previous studies on color stability have shown that colored beverages such as coffee, soda, tea and wine cause different degrees of staining on composite resins [3].

Polywave light-emitting diodes (LED) emits a light spectrum with varying wavelength

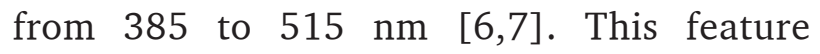
permits the curing of composite resins even when these contain different photoinitiators [8]. Composite resins to bleach teeth may be more susceptible to color change because they usually contain different photoinitiators which can influence on their curing and consequently in their properties $[8,9]$. The literature is scarce on studies evaluating the microhardness and color change of composite resins for bleached teeth, using polywave LEDs.

Thus, the aim of this study is to evaluate the microhardness and color stability of composite resin to bleach teeth, photocured by two generations of light curing devices after immersion in wine. The null hypotheses tested was that there was no statistical difference in microhardness and color change between two types of composite resins cured by two generations of LED light, when used for curing composites for bleached teeth after immersion of the specimens in the staining solution.

\section{MATERIAL AND METHODS}

\section{Specimen Preparation}

Three composite resins were used: two contain camphorquinone and Lucerin-TPO (Tetric N-Ceram shade A1, Ivoclar Vivadent, Schaan, Liechtenstein and Vit-l-escence shade WO Ultradent Products Inc., South Jordan, UT, USA) [2,8], and another only camphorquinone as negative control (Filtek Z350 shade WD, 3M ESPE Dental Products ${ }^{\mathrm{TM}}$, St. Paul, MN, USA). Two types of LED devices were used: monowave (Radii, SDI, Victoria, Australia) and polywave (Valo, Ultradent, Products Inc., South Jordan, UT, USA). The composite resins and LED devices are described in Table 1. 
Table 1 - Composite resins and curing light LEDs were used in this study

\begin{tabular}{|c|c|c|c|c|c|}
\hline Materials & Color & Composition & $\begin{array}{c}\text { Mean } \\
\text { particle size }\end{array}$ & $\begin{array}{l}\% \text { Filler } \\
\text { (by vol) }\end{array}$ & Manufacturer \\
\hline $\begin{array}{l}\text { Tetric N-Ceram (na- } \\
\text { nohybrid) }\end{array}$ & $\mathrm{A} 1$ & $\begin{array}{l}\text { Bis-GMA, UDMA, TEGDMA, } \\
\text { barium glass, barium glass and } \\
\text { aluminum, highly disperse silica, } \\
\text { mixed oxides, prepolymers }\end{array}$ & $\begin{array}{c}40 \mathrm{~nm} \\
3000 \mathrm{~nm}\end{array}$ & $55-57 \%$ & $\begin{array}{l}\text { Ivoclar Vivadent, Schaan, } \\
\text { Liechtenstein }\end{array}$ \\
\hline $\begin{array}{l}\text { Vit-I-escence (micro } \\
\text {-hybrid) }\end{array}$ & WO & $\begin{array}{c}\text { BisGMA, barium borosilicate and } \\
\text { other fillers, camphorquinone, } \\
\text { an amine co-initiator and a proprie- } \\
\text { tary initiator }\end{array}$ & $0.7 \mu \mathrm{m}$ & $58 \%$ & $\begin{array}{l}\text { Ultradent Products Inc., South } \\
\text { Jordan,UT,USA }\end{array}$ \\
\hline Filtek Z350 (nanofill) & WD & $\begin{array}{l}\text { Bis-GMA, Bis-EMA6, UDMA, } \\
\text { TEGDMA, zirconia, silica and cam- } \\
\text { phorquinone }\end{array}$ & $\begin{array}{l}5-20 \mathrm{nmn} . \mathrm{ag} . \\
0.6-4 \mu \mathrm{mag} .\end{array}$ & $59.5 \%$ & $\begin{array}{l}\text { 3M/ESPE Dental Products, St } \\
\text { Paul, MN, SA }\end{array}$ \\
\hline Curing Light & Type & Wavelength & \multicolumn{2}{|c|}{ Intensity } & Manufacturer \\
\hline Valo & $\begin{array}{l}\text { Third generation or } \\
\text { Polywave }\end{array}$ & $395-480 \mathrm{~nm}$ & \multicolumn{2}{|c|}{$\sim 1000 \mathrm{~mW} / \mathrm{cm}^{2}$} & $\begin{array}{l}\text { Ultradent Products Inc., South } \\
\text { Jordan,UT,USA }\end{array}$ \\
\hline Radii-Cal & $\begin{array}{l}\text { Second generation } \\
\text { or monowave }\end{array}$ & $440-480 \mathrm{~nm}$ & \multicolumn{2}{|c|}{$\sim 1200 \mathrm{~mW} / \mathrm{cm}^{2}$} & SDI Limited, Victoria, Australia \\
\hline
\end{tabular}

Twenty discs for each material were obtained using a Teflon matrix ( $5 \mathrm{~mm}$ diameter $\times 1.5 \mathrm{~mm}$ thick). The resin composite was then inserted into one increment and covered with a glass slide. Then, ten specimens from each resin were photo-cured by the monowave or polywave LED device for $40 \mathrm{~s}$. Planning and polishing were performed with silicon carbide sandpaper in the order of decreasing granulation (\# 600 and \# 1200). Diamond polishing suspension $(1 \mu \mathrm{m})$ was applied with a felt disc for final polishing for $60 \mathrm{~s}$ (APL4, Arotec S.A. Ind Com, Cotia, SP, Brazil). The samples were washed for $10 \mathrm{~min}$ in an ultrasound device (Cristófoli, Campo Mourão, SP, Brazil), then kept at $100 \%$ relative humidity at $37^{\circ} \mathrm{C}$ for $24 \mathrm{~h}$.

\section{Microhardness Analysis}

The samples were subjected to microhardness analysis (Shimadzu HMV 2000, Shimadzu Corporation, Kyoto, Japan) using a Knoop diamond under $25 \mathrm{~g}$ for $30 \mathrm{~s}$. Five indentations were made with $100 \mu \mathrm{m}$ distance between each indentation. Thens, the arithmetic mean was calculated.

\section{Color Change}

Color change $\Delta \mathrm{E}$ analysis was performed using a reflection spectrophotometer (UV Visible, Model UV-2450, Shimadzu, Kyoto, Japan). The $\Delta \mathrm{E}$ was calculated using the CIE $\mathrm{L} * \mathrm{a} * \mathrm{~b} *$, established by the Commission Internationale I'Eclairaga - (CIE). The axial "L" is known as luminosity, which ranges from 0 (black) to 100 (perfect white). The coordinate "a" represents the amount of red (positive values) and green (negative values), while the coordinate " $b$ " is the amount of yellow (positive value) and blue (negative values). Five readings were taken for each surface and the an average of the readings was obtained. To standardize the reading area, the samples were always positioned in the same way. solution

Immersion of the specimens in the staining

The specimens from each group were immersed individually in vials containing $10 \mathrm{ml}$ of red wine (Concha y Toro, Cabernet Sauvignon, $\mathrm{pH}=3.41$; Chile) for one week, which is equivalent to seven months to 
immersion [10]. After this period, the specimens were rinsed in distilled running water for $3 \mathrm{~min}$ and immersed in $10 \mathrm{ml}$ of distilled water for $24 \mathrm{~h}$ at $37^{\circ} \mathrm{C}$.

\section{Final Microhardness and Color Analyses}

The same microhardness and color analyses were performed as described above. The differences in the $\mathrm{L}^{*}(\Delta \mathrm{L}), \mathrm{a}^{*}(\Delta \mathrm{a})$, and $\mathrm{b} *(\Delta \mathrm{b})$ values were determined and the overall color change was calculated: $\Delta \mathrm{E}=$ $[(\Delta \mathrm{L}) 2+(\Delta \mathrm{a}) 2+(\Delta \mathrm{b}) 2] 1 / 2$.

\section{Statistical Analysis}

The software StatView version 5.0 (SAS Institute, Cary, NC, USA) was used for statistical analysis. The assumptions of equality of variances and normal distribution of data were checked using the Bartlett and ShapiroWilk tests, respectively. Since homogeneity was not achieved, the microhardness results were analyzed using the Kruskal-Wallis test, followed by the Mann-Whitney test for multiple comparisons. To compare the evaluations times of microhardness the Wilcoxon test was used. Color changes were evaluated by two-way analysis of variance (ANOVA) and the Tukey test for multiple comparisons. The significance level was set as 5\%.

\section{RESULTS}

Comparison of the composite resins before immersion in wine, showed that Vitl-escence (Monowave LED $p=0,0011$, Polywave LED $\mathrm{p}=0,0350$ ) and Filtek Z350 (Monowave LED $\mathrm{p}=0,0002$, Polywave LED $\mathrm{p}=0,0006)$ composite resins had statisticaly superior microhardness values compared with Tetric N-Ceram for all conditions, rejecting the null hypotheses (Table 2). No statistically significant difference between the two generations of LEDs was found for microhardness data (Table 2). There was a statistically significant decrease between the baseline and final periods when the monowave device was used for Vit-1-escence $(\mathrm{p}=0,0469)$ and Filtek Z350 ( $\mathrm{p}=0,0218)$ composite resins, and when the polywave device used for Filtek Z350 ( $\mathrm{p}=0,0051$ ) composite resin (Table 2).

Table 2 - Results regarding the baseline and final microhardness measurement of groups submitted to wine

\begin{tabular}{|c|c|c|c|c|}
\hline & & $\begin{array}{l}\text { Tetric-N } \\
\text { Ceram }\end{array}$ & $\begin{array}{c}\text { Vit-I- } \\
\text { escence }\end{array}$ & Filtek Z350 \\
\hline \multirow{2}{*}{ Baseline } & $\begin{array}{l}\text { Radii-Cal } \\
\text { Monowave }\end{array}$ & $61.47 \pm 3.4^{\mathrm{aB}}$ & $71.66 \pm 3.1^{\mathrm{aA}}$ & $73.24 \pm 6.9$ \\
\hline & $\begin{array}{c}\text { Valo } \\
\text { Polywave }\end{array}$ & $63.87 \pm 5.3^{\mathrm{aB}}$ & $68.89 \pm 4.8^{\text {aA }}$ & $72.54 \pm 3.9$ aA \\
\hline \multirow{2}{*}{ Final } & $\begin{array}{l}\text { Radii-Cal } \\
\text { Monowave }\end{array}$ & $59.15 \pm 2.6 \mathrm{aB}$ & $68.33 \pm 2.2^{a A^{*}}$ & $67.13 \pm 4.2^{a A^{*}}$ \\
\hline & $\begin{array}{c}\text { Valo } \\
\text { Polywave }\end{array}$ & $59.74 \pm 3.2 \mathrm{aC}$ & $68.33 \pm 1.8^{\text {aA }}$ & $65.70 \pm 1.9^{a B^{\circ}}$ \\
\hline
\end{tabular}

Equal letters indicate no statistically significant differences. Lowercase referring in columns and uppercase referring in rows. * Indicate a statistically significant difference between the baseline and final periods.

Regarding the $\Delta \mathrm{E}$, there was no statistically significant difference between the two generations of LEDs studied for Vit-l-escence composite resin $(P=0,798)$, which had the lowest $\Delta \mathrm{E}$ values (Table 3 ). Comparison of the composite resins showed, a higher $\Delta \mathrm{E}$ value for Filtek Z350, using the monowave device. However, when the polywave device was used, Filtek Z350 and Tetric- $\mathrm{N}$ Ceram had similar $\Delta \mathrm{E}$ values $(\mathrm{p}=$ 0,979 , Table 3 ). The $\Delta$ a values presented no statistically significant difference for LEDs type $(\mathrm{p}=0,855)$. However, for the $\Delta \mathrm{L}$ and $\Delta \mathrm{b}$ values when differences were found opposite performances occurred according to different composites (Table 3). Comparison of the composite resins showed no difference for $\Delta \mathrm{L}$ ( $\mathrm{p} \leq 0,05$, Table 3$)$. 
Table 3 - Results for the overall color change of groups immersed in red wine

\begin{tabular}{|c|c|c|c|c|c|c|c|c|c|c|c|c|}
\hline & \multirow[b]{2}{*}{$\Delta \mathrm{L}$} & \multicolumn{4}{|c|}{ Tetric-N Ceram } & \multicolumn{4}{|c|}{ Vit-I-escence } & \multicolumn{3}{|c|}{ Filtek Z350 } \\
\hline & & $\Delta \mathbf{a}$ & $\Delta \mathbf{b}$ & $\Delta \mathrm{E}$ & $\Delta \mathrm{L}$ & $\Delta \mathbf{a}$ & $\Delta \mathbf{b}$ & $\Delta \mathrm{E}$ & $\Delta \mathrm{L}$ & $\Delta \mathbf{a}$ & $\Delta b$ & $\Delta \mathrm{E}$ \\
\hline $\begin{array}{l}\text { Radii-Cal } \\
\text { Siglewave }\end{array}$ & $\begin{array}{c}-0,98 \\
\mathrm{aA}\end{array}$ & $\begin{array}{c}0,29 \\
a B\end{array}$ & $\begin{array}{l}1,73 \\
a B\end{array}$ & $\begin{array}{c}2,86 \pm 0,6 \\
\mathrm{aA}\end{array}$ & $\begin{array}{c}-0.73 \\
a A\end{array}$ & $\begin{array}{r}0,11 \\
a A B\end{array}$ & $\begin{array}{c}0,99 \\
a A\end{array}$ & $\begin{array}{c}2,13 \pm 0,8 \\
a A\end{array}$ & $\begin{array}{c}-1.52 \\
b A\end{array}$ & $\begin{array}{c}-0.01 \\
a A\end{array}$ & $\begin{array}{c}3.88 \\
b C\end{array}$ & $\begin{array}{c}4.97 \pm 1.0 \\
\mathrm{bB}\end{array}$ \\
\hline $\begin{array}{c}\text { Valo } \\
\text { Polywave }\end{array}$ & $\begin{array}{c}-0,79 \\
\mathrm{aA}\end{array}$ & $\begin{array}{c}-0,08 \\
a A\end{array}$ & $\begin{array}{l}3,01 \\
b B\end{array}$ & $\begin{array}{c}4,14 \pm 0,7 \\
\text { bB }\end{array}$ & $\begin{array}{l}-0.75 \\
b A\end{array}$ & $\begin{array}{l}0,19 \\
a A B\end{array}$ & $\begin{array}{l}1,23 \\
a A\end{array}$ & $\begin{array}{c}2,26 \pm 0,7 \\
a A\end{array}$ & $\begin{array}{c}-1.47 \\
\mathrm{aA}\end{array}$ & $\begin{array}{c}0.23 \\
a B\end{array}$ & $\begin{array}{l}3.37 \\
\mathrm{aC}\end{array}$ & $\begin{array}{c}4.07 \pm 1.1 \\
\mathrm{aB}\end{array}$ \\
\hline
\end{tabular}

Equal letters indicate no statistically significant differences. Lowercase referring in columns and uppercase referring in rows in each color parameter

\section{DISCUSSION}

The evaluation of mechanical and physical properties can provide an indirect measure to preview the monomers conversion in composite resins, such as microhardness and overall color change $(\Delta \mathrm{E}) \quad[8,9]$. Although no differences were found for surface microhardness between both LED devices, differences were observed for color parameters, thus rejecting the null hypothesis.

Some studies that evaluated the same composite resins used in the present study also did not find differences in surface microhardness between the monowave and polywave LEDs [8,9]. However, other studies that evaluated composite resins with LucerinTPO showed higher microhardness with the polywave than monowave LEDs [11-13]. In the present study, a significant reduction in microhardness for Vit-l-escence photocured by the monowave LEDs occurred after immersion in wine. This attributed to the acidic $\mathrm{pH}$ and presence of alcohol in wine, which can affect the unreacted monomers of the composite resin $[14,15]$. The composition may also influence because the resins for bleaching teeth contain other initiators combined with camphorquinone $[16,17]$.

Evaluation of the composite resins photocured by the same device showed microhardness values superior to that of the nanoparticulate resin (Filtek Z350) before immersion in wine, corresponding to the literature [16-18]. There are two forms of inorganic particles in all nanoparticulate resins: dispersed - silica particles, measuring approximately $20 \mathrm{~nm}$; and adhering, silicazirconia nanocomplexes that, behave as a single structure, measuring an average of $75 \mathrm{~nm}$ [16]. The union of these two forms provides a higher percentage of charged particles, providing the material with greater resistance, compared with nanohybrid and microhybrid resins, which tend to be less resistant because they have fewer filling agents [17]. However, a significant decrease in microhardness occurred after the immersion of the nanoparticulate resin in red wine This composite resin contains the TEGDMA monomer,which has greater capacity for water absorption compared with other types monomers (Bis-GMA and UDMA), making it more susceptible to the degradation of unreacted monomers [19].

The physicochemical properties of the monomers used in the resin matrix can also influence the resistance to pigmentation, resulting in overall $\Delta \mathrm{E}$ [3]. Various methods can be used to assess color, such as guide scales, image analysis, colorimeter or spectrophotometers. Since spectrophotometers allows objective assessment and provide accurate quantitative data, the method was chosen for this study [20]. 
For the specimens immersed in wine, the acidic $\mathrm{pH}$ may have been responsible for the color change by altering the surface roughness of the specimens, however more studies are needed to confirm this possibility [21]. The results obtained in the present study contradict the literature i.e. it was observed that the higher the action spectrum of curing light, the greater the scope of the monomers, promoting better polymerization, and less degradation of the organic matrix and composite pigmentation [22]. The present results were not homogenous with regard to these aspects. This because for one type of composite resin (Vit-l-escence) LED units had no influence for the other tyoes (Tetric-N Ceram and Filtek Z350) opposite behaviors occurred.

$\Delta \mathrm{E}$ indicates the relative overall color change and according to Inokoshi et al. [22], the values of $\Delta \mathrm{E}<1$ are regarded as unseen by the human eye. Values $1<\Delta \mathrm{E}<3.3$ are considered noticetable skilled operators, but clinically acceptable. Values of $\Delta \mathrm{E}>3.3$ are considered clinically unacceptable [23]. Vitl-escence resin showed the lowest $\Delta \mathrm{E}$, and was clinically acceptable $(\Delta \mathrm{E}<3.3)$. This composite resin is the only one among the other composites tested that does not contain TEGDMA monomer.It has greater capacity for water absorption as cited above, causing the resin to be more susceptible to pigmentation [19].

Separating the parameters, opposite behaviors of composite resins were noted when photocured by different LEDs. Changes in the ${ }^{*} \mathrm{~L}$ parameters can occur because the acidic $\mathrm{pH}$ of wine may reduce the surface gloss and consequently the lightness of color [14]. Furthermore, the complex combination of pigments presents in wine, such as anthocyanins that can range from red through blue to purple, can form complexes with some oral proteins, causing tongue and tooth discoloration, varyng the *a and *b parameters $[20,21,24,25]$.

It is important to emphasize that although the shades of composite resins for whitened teeth were used, these shades were not the same for all composite resins because theses resins had confirmation in the literature about their photoinitiators, being a limitation of this study. Furthermore, the literature has shown studies where composites were manipulated in the laboratory in an attempt quantify photoinitiators and standardize composite resin samples $[26,27]$. Schneider et al. [27], showed that formulations containing TPO exhibited higher reactivity than that with camphoroquinone but lower depth of cure. However, this does not agree with the pratical experiences of dentists, demonstrating the high medical character and relevance of the present study, with its focus on using resins commonly found in the dental market. Moreover, additional studies are necessary to evaluate other properties of composite resins when photocured by different light-curing units.

\section{CONCLUSION}

In general, the composition of composite resins had more influence on microhardness and color change than the type of lightcuring units used. A decreased microhardness occurred to Vit-l-escence for monowave and to Filtek Z350 for both LED devices. A clinically perceptible color change was observed to Tetric-N Ceram for polywave and to Filtek Z350 for both LED devices.

\section{Acknowledgements}

The authors would like to thank the financial support of the São Paulo Research Foundation (FAPESP), process 2014 / 24478-0. 


\section{Declaration of conflicting interests}

The author(s) declared no potential conflicts of interest with respect to the research, authorship, and/or publication of this article.

\section{Funding Statement}

This study was founded by São Paulo Research Foundation - FAPESP [grant number 2014 / 24478-0].

\section{REFERENCES}

1. Ikemura K, Endo T. A review of the development of radical photopolymerization initiators used for designing light curing dental adhesives and resin composites. Dent Mater J.2010 0ct;29(5):481-501.

2. Porto IC, Soares LE, Martin AA, Cavalli V, LiporoniPC. Influence of the photoinitiator system and light photoactivation units on the degree of conversion of dental composites. Braz Oral Res. 2010 0ct-Dec;24(4):475-81

3. Catelan A, Briso AL, Sundfeld RH, Goiato MC, dos Santos PH. Color stability of sealed composite resin restorative materials after ultraviolet artificial aging and immersion in staining solutions. JProsthet Dent. 2011 Apr;105(4):236-41. doi: 101016/S0022-3913(11)60038-3.

4. Price RB, Ferracane JL, Shortall AC. Light-curing units: a review of what we need to know. JDent Res. 2015:94(9):1179-86

5. Briso AL, Caruzo LP, Guedes AP, Catelan A, dos Santos PH. In vitro evaluation of surface roughness and microhardness of restorative materials submitted to erosive challenges. Oper Dent. 2011 Jul-Aug;36(4):397-402. doi: 10.2341/10356-L.

6. Ilie N, Hickel R. Can CQ be completely replaced by alternative initiators in dental adhesives? Dent Mater J.2008;27(2):221-28.

7. Lucey SM, Santini A, Roebuck EM. Degree of conversion of resin-based materials cured with dual-peak or single-peak LED light-curing units. Int J Paediatr Dent. 2015 Mar;25(2):93-102. doi: 10.1111/ipd.12104..

8. Santini A, Miletic V,Swift MD, Bradley M. Degree of conversion and microhardness of TPO-containing resin-based composites cured by polywave and monowave LED units. JDent. 2012 Jul;:40(7):577-84. doi:101016/j. jdent.2012.03.007.

9. Sim JS, Seol HJ, Park JK, Garcia-Godoy F, Kim HI, Kwon YH. Interaction of LED light with coinitiator-containin composite resin: effect of dual peaks. JDent. 20120ct;40(10):836-42. doi: 10.1016/j.jdent.2012.06.008.

10. Ertas E, Guler AU, Yucel AC, Koprulu H, Guler E. Color stability of resin composites after immersion in different drinks. Dent Mater. 2006;25(2):371-6

11. Shimokawa C, Sullivan B, Turbino ML, Soares CJ, Price RB. Influence of emission spectrum and irradiance on light curing of resin-based composites. Oper Dent. 2017;42(5):537-47. doi:10.2341/16-349-L.
12. Price RB, Fahey J, Felix CM. Knoop hardness of five composites cured with single-peak and polywave LED curing lights. Quintessence Int. 2010;41(10):18191

13. Lee DS, Jeong TS, KimS, Kim HI, Kwon YH. Effect of dual LED unit on the polymerization of coinitiator-containing composite resins. Dent Mater J. 2012;31(4):656-61

14. BansalK, Acharya SR, Saraswathi V.Effect of alcoholic and non-alcoholic beverages on color stability and surface roughness of resin composites: An in vitro study. J Conserv Dent. 2012 Jul;15(3):283-8. doi: 10.4103/0972-0707.97961.

15. Kumar MS, Ajay R, Miskeen Sahib SA, Chittrarasu M, Navarasu M, Ragavendran N, Burhanuddin Mohammed OF.Color stability assessment of two different composite resins with variable immersion time using various beverages: an in vitro study. J Pharm Bioallied Sci. 2017 Nov;9(Suppl 1):S161-S165. doi:10.4103/jpbs.JPBS_149_17.

16. Júnior PCM, Cardoso RM, Magalhães BG, et al. Selecionando corretamente as resinas compostas: revisão de literatura. Int J Dent. 2011;10:91-6.

17. Ferracane JL. Resin composite: state of the art. Dent Mater. 2011 Jan;27(1):2938. doi:10.1016/j.dental.201010.020.

18. Rosa RS, Balbinot CE, Blando E, Mota EG, Oshima HM, Hirakata L, Pires LA, Hübler R. Evaluation of mechanical properties on three nanofilled composites. Stomatologija. 2012;14(4):126-30.

19. Rey N, Benbachir N, Bortolotto T, Krejci I. Evaluation of the staining potential of a caries infiltrant in comparison to other products. Dent Mater J. 2014:33(1):86-91.

20. Borges AB, Caneppele TMF, Luz M, PucciC, Torres C. Color stability of resin used for caries infiltration after exposure to different staining solutions. Oper Dent. 2014 Jul-Aug;39(4):433-40. doi: 10.2341/13-150-L.

21. Tornavoi DC, Agnelli JM, Panzeri H, Dos Reis AC. Color change of composite resins subjected to accelerated artificial aging. ndian J DentRes. 2013 SepOct;24(5):605-9. doi: 10.4103/0970-9290.123390.

22. Rueggeberg FA. State-of-the-art:Dental photo- curing: a review. Dent Mater. 2011 Jan;27(1):39-52. doi: 10.1016/j.dental.2010.10.021.

23. Inokoshi S, Burrow MF, Kataumi M, Yamada T, Takatsu T. Opacity and color changes of tooth-colored restorative materials. Oper Dent. 1996;21(2):73-80.

24. De Alencar e Silva Leite ML, da Cunha Medeiros e SilvaFD, Meireles SS, Duarte RM, Andrade AK. The effect of drinks on color stability and surface roughness of nanocomposites Eur J Dent. 2014 Jul;8(3):330-6. doi: 10.4103/13057456.137640 .

25. Gaglianone LA, Martins JD, Rossi TR, Saraiva LO, Cavalcanti AN, Mathias P Changes on the color parameters of air-abraded resin composite exposed to different colored beverages. J Investig Clin Dent. 2011 Aug;2(3):201-6. doi: 10.1111/j.2041-1626.2011.00063.x.

26. Silami FD, Mundim FM, Garcia LF, Sinhoreti MA, Pires-de-Souza Fde C. Color stability of experimental composites containing different photoinitiators. J Dent. 2013 Aug;41Suppl 3:e62-6. doi:101016/j.jdent.2012.10.009.

27. Schneider LF, Cavalcante LM, Prahl AS, Pfeifer CS, Ferracane JL. Curing efficiency of dental resin composites formulated with camphoroquinone or trimetylbenzoyl-diphenyl-phosphine oxide. Dent Mater.2012 Apr;28(4):392-7. doi:10.1016/j.dental.2011.11.014.

\section{Prof. Ticiane Cestari Fagundes} (Corresponding address)

Araçatuba School of Dentistry, UNESP - São Paulo State University

Department of Restorative Dentistry

José Bonifácio St, 1193, Araçatuba, SP, Brazil

ZIP Code - 16015-050

Date submitted: 2019 Mar 22

E-mail: ticiane.fagundes@unesp.br Accept submission: 2019 May 21 